\title{
Geospatial Modeling of Blue Carbon Ecosystem Coastal Degradation in Jakarta Bay
}

\author{
Nasir Sudirman ${ }^{1,4}$, Muhammad Helmi ${ }^{2,3}$, Hadiwijaya L. Salim ${ }^{4}$ \\ ${ }^{1}$ Magister Program of Environmental Science, School of Postgraduate Studies, \\ Diponegoro University, Semarang - Indonesia \\ ${ }^{2}$ Oceanography Department of Science, Faculty of Fisheries and Marine Science, \\ Diponegoro University, Semarang - Indonesia \\ ${ }^{3}$ PUI-PKMBRP (Pusat Unggulan IPTEK - Pusat Kajian Mitigasi Bencana dan Rehabilitasi Pesisir) \\ ${ }^{4}$ Marine Research Center, Research and Human Resources Agency for Marine and Fisheries Ministry of Marine Affairs \\ and Fisheries Republic of Indonesia \\ Email corresponding author: nsr.sudirman@gmail.com
}

\begin{abstract}
Jakarta Bay is shallow water which is used for various activities, currently experiencing environment, soil, and sediment degradation. Jakarta Bay experienced rapid development, population growth, increased economic activity and utilization of coastal resources. The development of Jakarta Bay is carried out to balance land necessity and overcome the problem of land subsidence through reclamation and construction of sea dikes. Ecosystem services are the contribution of various interrelated ecological structures and functions, mangrove ecosystems provide services as an important part of the carbon cycle. Mangroves use $\mathrm{CO}_{2}$ for photosynthesis and store it in Biomass and sediment stock. Mangrove ecosystems in Jakarta Bay have been degraded and deforested due to land conversion for settlement, facilities, and other activities, in line with the increasing population. The calculation of the service value of mangrove ecosystems is limited to economic valuation and descriptive account, geospatial modelling has not been widely carried out, this has caused widespread and temporal unknown data on ecosystem services. The Coastal Blue Carbon geospatial modelling used in this study requires land use classification data input based on the interpretation of Landsat satellite's images and global carbon deposits in mangrove ecosystems while carbon prices are based on Social Cost Carbon (SCC), Greenhouse Gas Initiative (RGGI) and International Voluntary Market Price (IVMP). This study produced a map of the dynamics of carbon stock, sequestration, emissions, accumulation and net present value of carbon. The output of these maps is expected to be a reference for sustainable mangrove management, coastal area planning optimization with mangrove ecosystem protection so it can be part of climate change mitigation efforts in Jakarta Bay.
\end{abstract}

Keywords: Geospatial, ecosystem, blue carbon, Jakarta

\section{INTRODUCTION}

The coastal region is a transitional area (Asyiawati and Akliyah, 2014), which is a transition between freshwater and brine so they have high natural resources (Parawansa, 2007). Sedimentation occurs in 13 river mouths along the bay, including Cisadane river to the west and Citarum river to the east. (P2O-LIPI, 2017). Sedimentation from rivers was identified since the 70s (Lubis, et al., 2007). Jakarta Bay is average shallow water of 15 meters (Pranowo et al., 2014), used for shipping, ports, tourism, fisheries, settlement, industry, and trade (Arifin and Mustikasari, 2014). Environmental degradation is indicated by the occurrence of phytoplankton blooms, while also experiencing heavy metal pollution (Kusuma et al., 2013). Land subsidence occurred from 1982 until 2010 and varied with an average of 1-15 cm/year and 20-28 cm/year (Abidin et al., 2015).

Ecosystem services are the contribution of various interrelated ecological structures and functions, mangrove ecosystems provide ecosystem services as organisms that are able to maintain the carbon cycle (Sudirman et al., 2018). According to (MEA, 2005), ecosystem services are defined into four basic categories, namely provision, regulation, culture and support. Mangrove ecosystems have ecological, economic and social values which are the main ecosystems on the coastal area (Saprudin and Halidah, 2012). Indonesia has a mangrove ecosystem of 3,112,989 ha which constitutes $22.6 \%$ of the total mangrove in the world (Giri et al. 2015), but is currently experiencing degradation of 30-50\% due to land conversion (Donato et al., 2012). Mangrove ecosystems grow in tidalzone, lagoons, and river estuaries (Kusmana et al., 2005). Mangrove ecosystems have the function of producing oxygen and absorbing carbon. Saparinto, (2007) in (Majid et al., 2016). Decomposition creates complex detritus, which enriches the productivity. (Suzana et al., 2011). 
Mangroves use $\mathrm{CO}_{2}$ for photosynthesis and store it in Biomass and sediment stock as climate change mitigation efforts (Ati et al., 2014). Mangroves absorb carbon dioxide and transform it into organic carbon (Bouillon et al., 2008; Alongi, 2014 (Murdiyarso et al., 2015).

Muara Gembong Subdistrict has a mangrove ecosystem (Asyiawati and Akliyah 2011), also some in Teluk Naga District, Tanggerang Regency, and Penjaringan District, in North Jakarta, covering an area of 9,749 ha (Parawansa, 2007). Mangrove cover in Muara Angke and Muara Gembong is below 20\% according to Santosa (2012) in Ambinari et al., (2016). Mangrove ecosystems in Jakarta Bay have been degraded and deforested due to land conversion for settlement, facilities, and other activities, in line with the increase in population and for aquaculture businesses (Ambinari et al., 2016). The consequences of global mangrove deforestation and changes in land use can cause carbon dioxide $\left(\mathrm{CO}_{2}\right)$ emissions to be around $10 \%$ or equivalent to $0.02-0.12 \mathrm{Mg} \mathrm{C}$ per year (Donato et al., 2011). The calculation of the mangrove ecosystem services value in Indonesia is done through a direct and indirect benefit approach. (Suzana et al., 2011; Saprudin and Halidah, 2012). Measurement and map of the ecosystem services as an input of resource management policies are experiencing inconsistent method constraints (Crossman et al., 2013) if there is damage, the compensation cannot be demanded based on its value in market value or even non-market value.

Jakarta Bay is experiencing rapid development and being affected by various human activities. Population growth demands the availability of land, increased economic activity, and utilization of resources and coastal environment, increasing these activities causes a decrease in carrying capacity and ecosystem services inside. The development of Jakarta Bay coastal area is carried out to compensate for land needs due to population growth and human activities as well as overcoming problems of land subsidence accompanied by sea level rise that causing tidal floods. The need for land is responded by the government through reclamation (Prasetyo et al., 2018), while to protect Jakarta's safety against flooding and slowing down land degradation through the construction of sea dikes (PTPIN, 2014).

The studies of ecosystem services that have already been carried out at this time are limited to economic valuation and descriptive account, spatial modelling with software has not been widely implemented, this has caused data on ecosystem services to be widely and temporally unknown. Spatial modelling used in this study resulted in the output of spatial and temporal maps regarding the dynamics of coastal blue carbon ecosystem services since 2004, 2018 to 2068. The output of these maps is expected to be a reference for sustainable mangrove management, coastal area planning optimization with mangrove ecosystem protection in order that it can be part of climate change mitigation efforts in Jakarta Bay.

\section{MATERIAL AND METHODS}

This modelling focuses on ecosystem services, spatially, providing biophysical, market and nonmarket output, based on planning, demonstrates the relationships between diverse ecosystem services, having modular and tiered approaches to accommodate various data availability and levels of knowledge systems (Guerry et al., 2012). Coastal Blue Carbon modelling is used to support geographic information systems. This modelling was developed by Natural Capital Project at Stanford University, where the guidelines used to carry out this program refer to the Invest Documentation (Nelson et al., 2018).

The satellite imagery used in this study uses Landsat in 2004 and 2018. In order to be used in spatial modeling of coastal blue carbon, these Landsat images need to be carried out radiometric and geometric corrections to eliminate atmospheric scattering, sequestration, and minimize light interference by the atmosphere (Phin et al. (2011), Kabiri, (2013) in (Helmi et al., 2018)). Calculation of the carbon deposits value in the mangrove ecosystem stored in the three main storage (Carbon Pool), namely biomass, carbon sediment, and litter. (Pendleton et al., 2012). Carbon values in biomass and sediment refer to the global carbon value of mangrove biomass at 84,912 $\mathrm{TCO}_{2} \mathrm{e} / \mathrm{Ha}$ and sediments at 2610,312 $\mathrm{TCO}_{2} \mathrm{e} / \mathrm{Ha}$ (Donato et al., 2011). The pricing of the value of carbon deposits refers to carbon prices based on the prices of Social Cost Carbon (SCC), Regional Greenhouse Gas Initiative (RGGI), and International Voluntary Market Price (IVMP) (Jerath, et al., 2016). The calculation of carbon values used in this study refers to the Invest Documentation (Nelson et al., 2018), including:

1. Carbon Storage

Stotal $=$ Sbiomass + Ssoil + Slitter

2. Carbon Emission 


$$
E p=D p \cdot\left(0.5 \frac{t-(r+1)}{H p}-0.5 \frac{t-r}{H p}\right)
$$

3. Clean Sequestration at this moment

$$
\mathrm{Vx}=\sum_{t=0}^{T} \frac{\operatorname{Pt}(C t, x-C t-1, x)}{(1+d) t}
$$

Description:

Sbiomass : The amount of carbon in the mangrove biomass

Ssoil : The amount of carbon in mangrove sediments

Slitter : The amount of carbon in the mangrove litter

Dp : Number of disturbed carbon stocks

Hp : The half-life of a disturbance

$r \quad:$ Year of transition

$T \quad:$ The number of years between the current date and the end of settlement land change

$p_{t} \quad:$ Price per ton of carbon in time

$C_{t, x} \quad:$ Carbon stock in pixels in time

$d \quad:$ Discount rate

$t \quad:$ Time stage

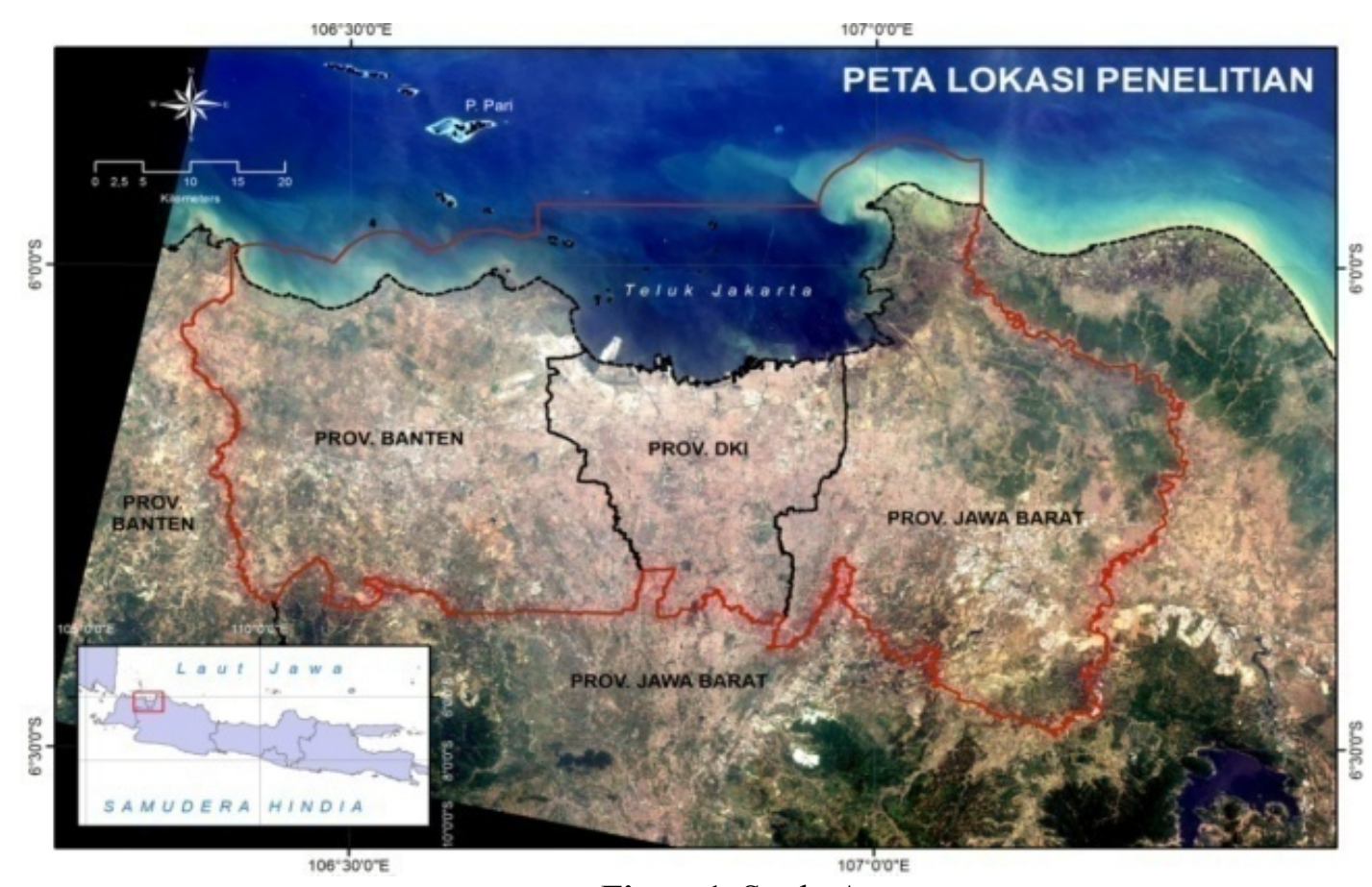

RESULTS AND DISCUSSION

Figure1. Study Area

Teluk Jakarta experienced changes in land use in both the coastal and central parts. Changes in land use in Jakarta Bay cause changes in the value of carbon in the mangrove ecosystem. This study examines changes in land use in 2004 and 2018 while changes in coastal blue carbon values were carried out from 2004 to 2018 and modelled carbon changes up to 2068. Changes in land use are shown in the following table: 
Table 1. Table of changes in land use in the Jakarta Bay in 2004 and 2018

\begin{tabular}{lrr}
\hline & Type of land use & \multicolumn{2}{c}{ Area of land use (Ha) } \\
\cline { 2 - 3 } & Year 2004 & Year 2018 \\
\hline Water & 89,324 & 87,648 \\
Open field & 44,462 & 9,018 \\
Mangrove & 12,903 & 4,002 \\
Plantation & 4,913 & 29,328 \\
Settlement & 139,764 & 172,204 \\
Grasses & 12,451 & 20,018 \\
Rice field & 55,696 & 20,580 \\
Fishpond & 13,771 & 24,181 \\
Vegetation & 65,552 & 72,404 \\
\hline
\end{tabular}

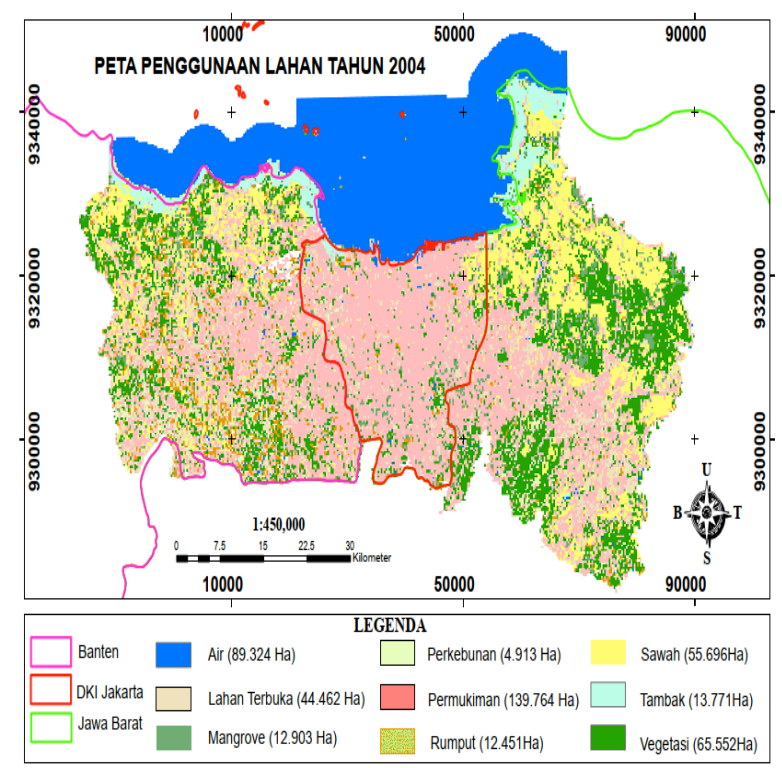

Figure 2. Map of land use in Jakarta Bay in 2004

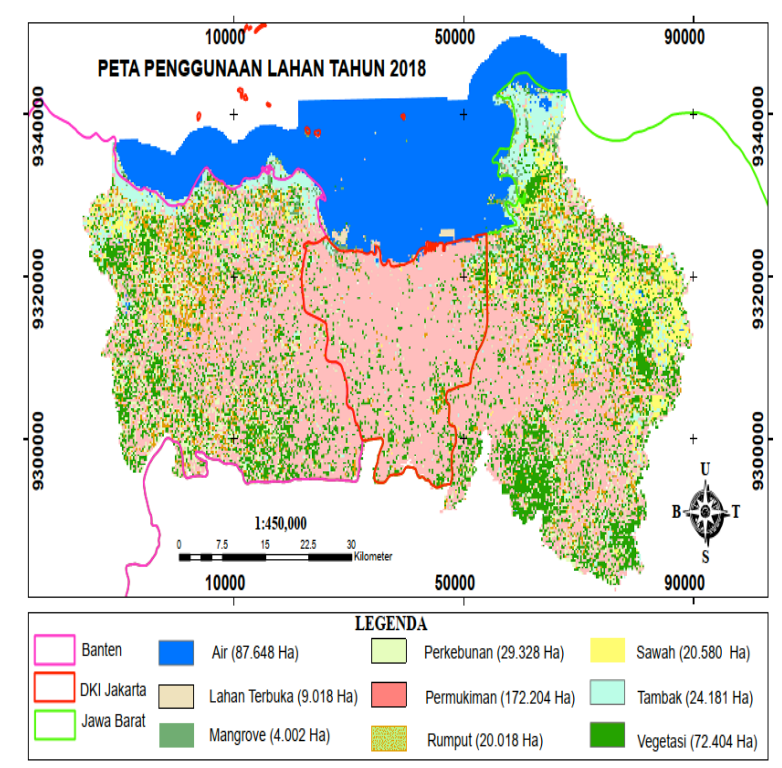

Figure 3. Map of land use in Jakarta Bay in 2018 
Land use is a major factor affecting carbon stocks in ecosystems that can be used to model carbon cycles (Houghton et al., 2003). Changes in land use in the Jakarta Bay area are shown in Table 1. Figure 2 shows a map of land use in 2004, while Figure 3 is a land use in 2018. The use of land as an area of water, open land, settlement, fishpond is land use that has no value carbon. Plantation, grass, rice fields and vegetation are land uses that have carbon values, but in modelling blue carbon coastal areas, only mangrove ecosystems are referred to as carbon values. (Nelson et al., 2018). Coastal marshes, mangroves, and seagrasses, in particular, store large amounts of carbon in sediments, leaves, and other forms of biomass. Land use besides mangroves in this model is considered to have no carbon value, such that despite changes in land use from other than mangrove to mangrove do not add carbon value from the use of plantation land, grass, rice fields and vegetation. Conversely, if there is a change in land use from mangrove to other than mangrove, it is a disturbance that has the potential to cause a reduction in coastal blue carbon value. Interference with coastal blue carbon has different properties depending on the changes. If mangroves turn into plantations, rice fields, fishponds, then the disturbance is a high impact disturbance because the change to land use causes the release of carbon from mangrove biomass and mangrove sediment due to the opening and excavation of the mangrove ecosystem. If it turns into water, open land, settlements then the disturbance is a medium impact disturbance because the change only causes the loss of mangrove biomass while the mangrove sediment still stores carbon (Nelson et al., 2018).

Stock carbon in 2004 amounted to 2,698,224121 tC/ha (Figure 4). In 2018 there was an increase in carbon in certain regions but also showed a reduction in carbon stock in other regions. The stock carbon value in 2018 varied where the highest carbon stock value was 40,428.36328 tC/ha and the lowest reached $3,407,566.25 \mathrm{tC} /$ ha (Figure 5). Stock carbon in 2004 and 2018 became a reference for software to model the amount of carbon stock in 2068. Figure 6 shows the estimated carbon stock in 2068 if the area of mangrove ecosystem in 2068 does not change land use or conversion, hence carbon stock values will be obtained at $137,456.4375 \mathrm{tC} /$ ha to $-3,407,774 \mathrm{tC} / \mathrm{ha}$.

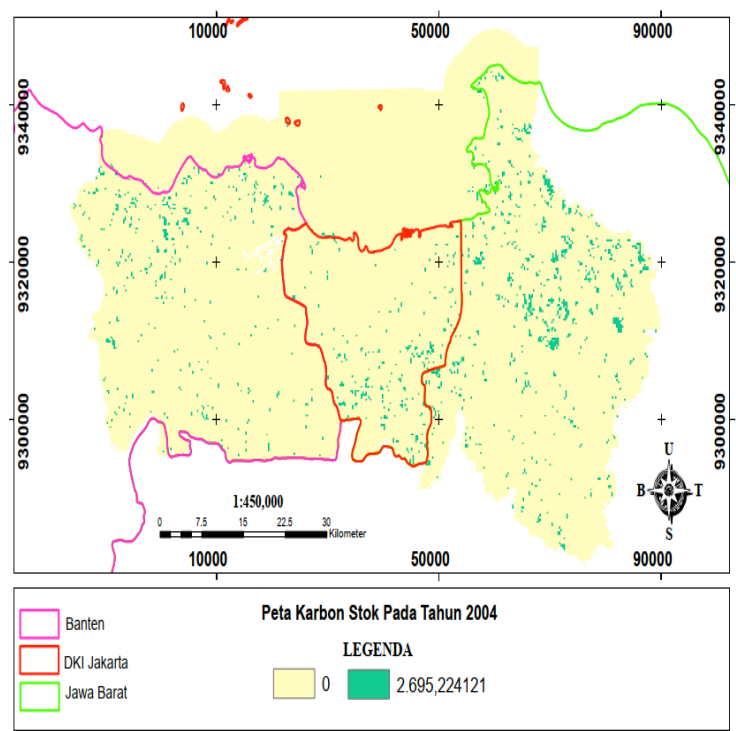

Figure 4. Stock carbon in 2004 


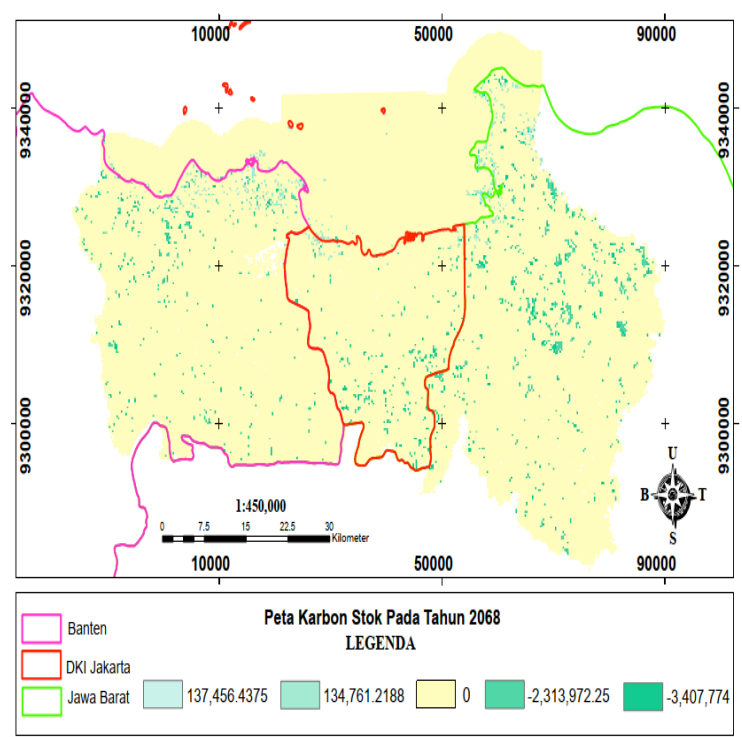

Figure 6. Stock carbon in 2068

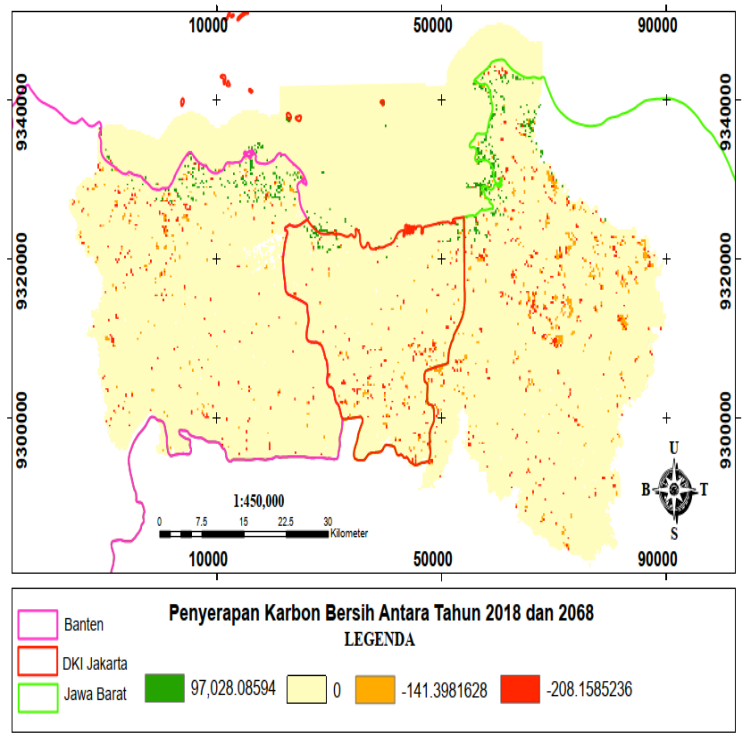

Figure 7. Net carbon sequestration between 2018 and 2068 


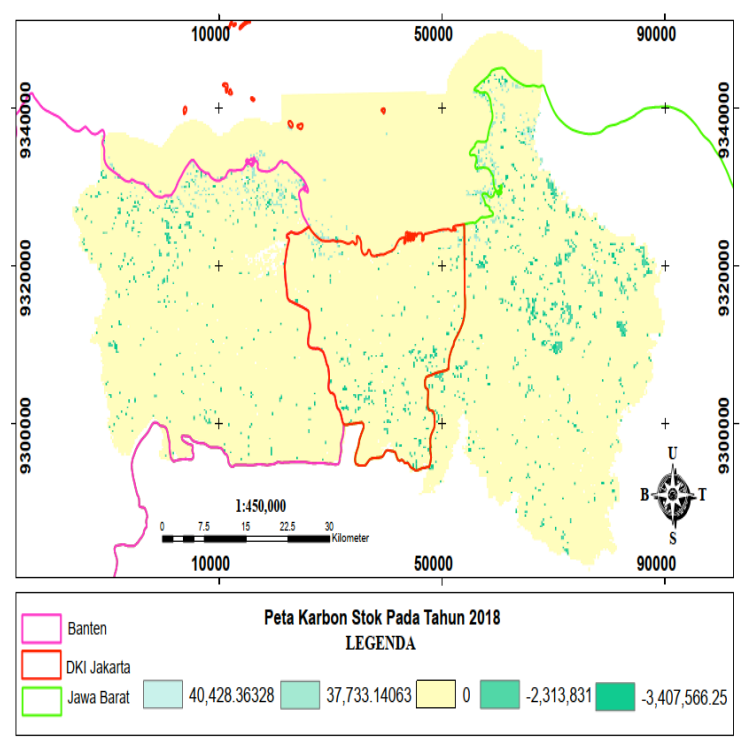

Figure 8. Stock carbon in 2018

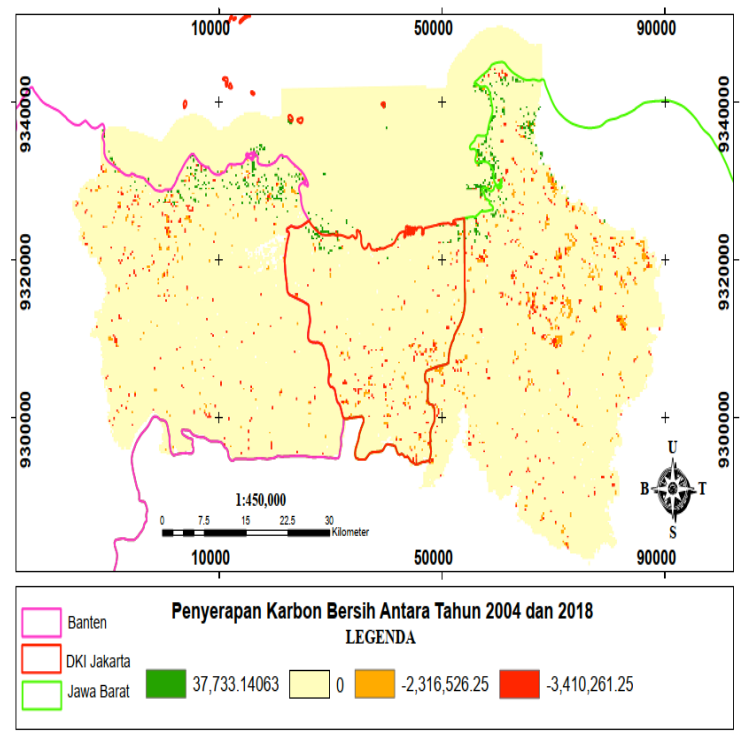

Figure 9. Net carbon sequestration between 2004 and 2018 


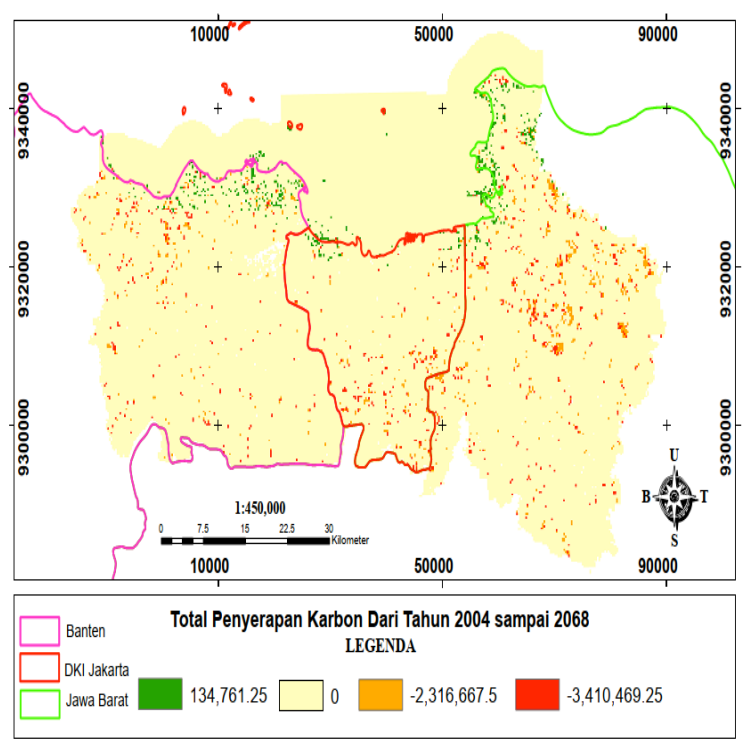

Figure 10. Total carbon sequestration from 2004 to 2068

The carbon uptake shown in Figure 7 is carbon uptake from 2004 to 2018 of 37,733,14063 tC/ha up to $-3,410,261.25 \mathrm{tC} / \mathrm{ha}$, where 2004 was the base calculation year. Figure 8 shows that carbon uptake in 2018 to 2068 is estimated to reach $97,028,08594 \mathrm{tC} /$ ha up to $-208,1585236 \mathrm{tC} /$ ha where the base year used is 2018 . Total carbon absorption for 50 years is $134,761.25 \mathrm{tC} / \mathrm{ha}$ up to $-3,410,469.25 \mathrm{tC} /$ ha Figure 9. Total carbon uptake will be achieved if land use is fixed up to 2068 where carbon values are obtained based on 2004-2018 land use inputs and carbon uptake in those years (Figure 10).

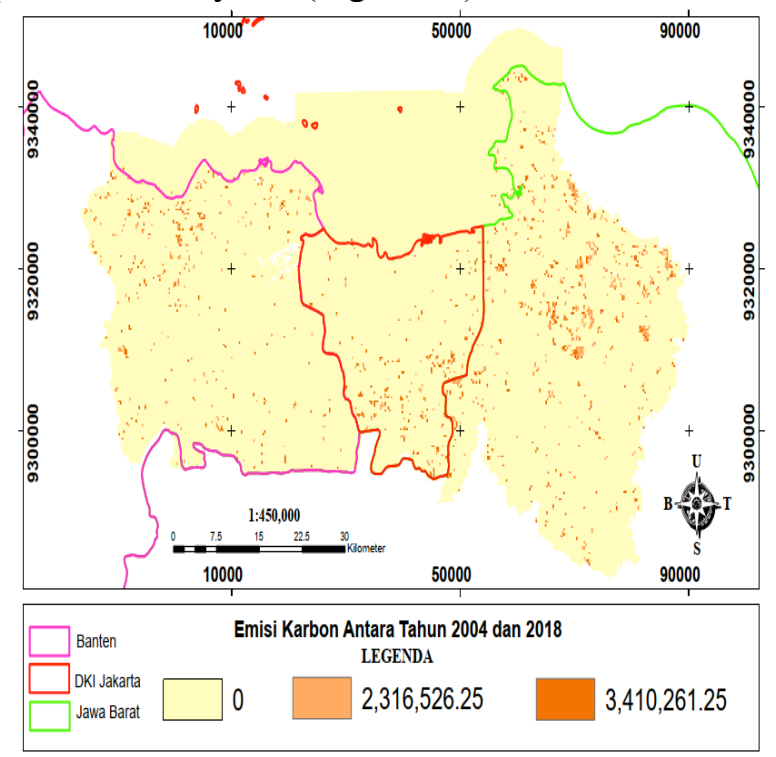

Figure 10. Carbon emissions between 2004 and 2018 


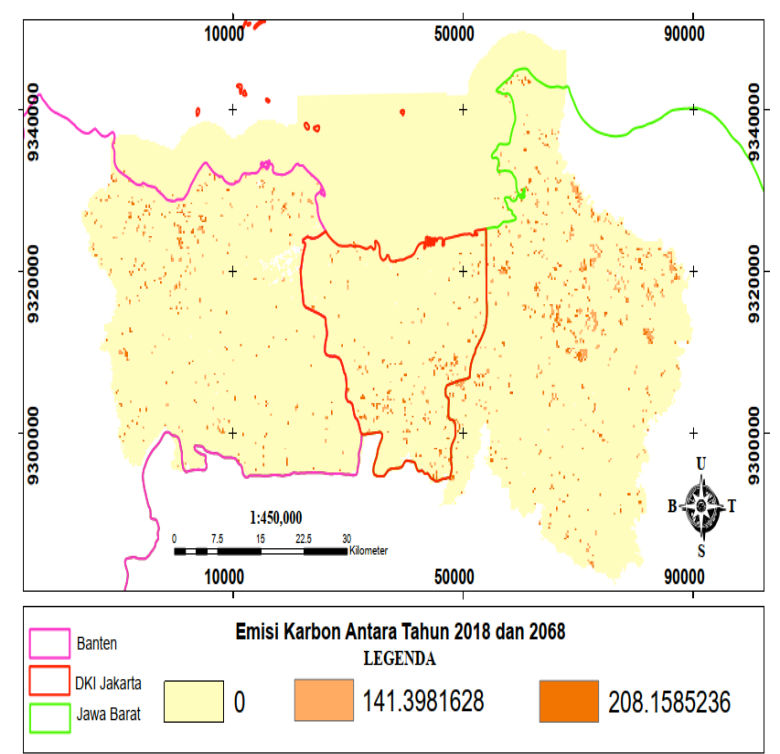

Figure 11. Carbon emissions between 2018 - 2068

Carbon emissions between 2004-2018 amounted to 2,316,526.25 tC/ha to 3,410,261.25 tC/ha. Emissions show the release of carbon from the mangrove ecosystem due to land conversion (Figure 10). Carbon emissions in 2068 are estimated to reach $141.3881628 \mathrm{tC} /$ ha to $208.1585236 \mathrm{tC} /$ ha (Figure 11).

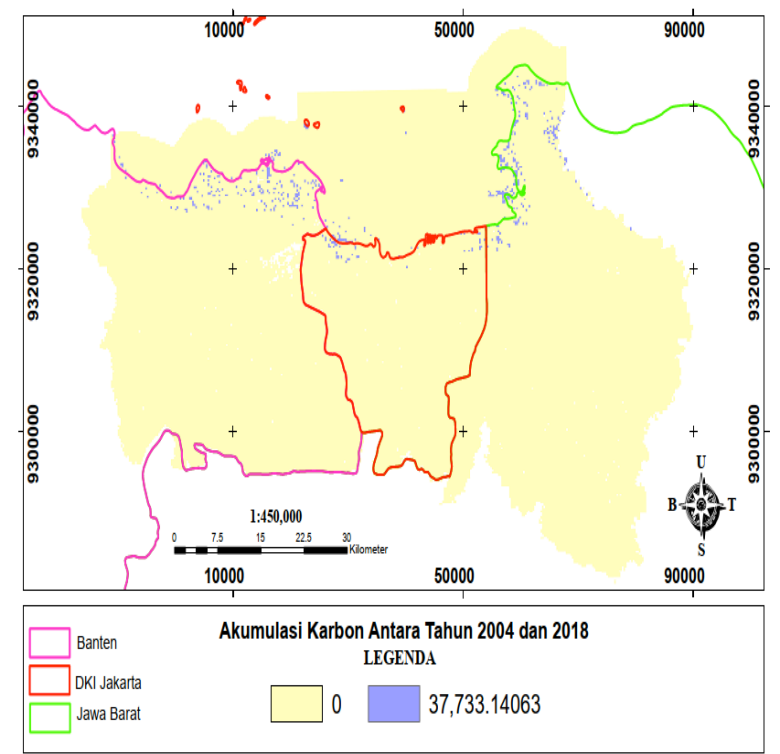

Figure 12. Carbon accumulation between 2004 and 2018

Carbon accumulation is the amount of carbon accumulated by biomass and sediment. Accumulation occurs all the time as long as there is no change in land use. Accumulation is affected by emissions and absorption by biomass and sediments either due to land changes or due to natural factors. Carbon accumulation values between 2004-2018 were 37,733.14063 tC/ha (Figure 12). Accumulation in 2018-2068 was $97,028,08594$ tC/ha (Figure 13). 


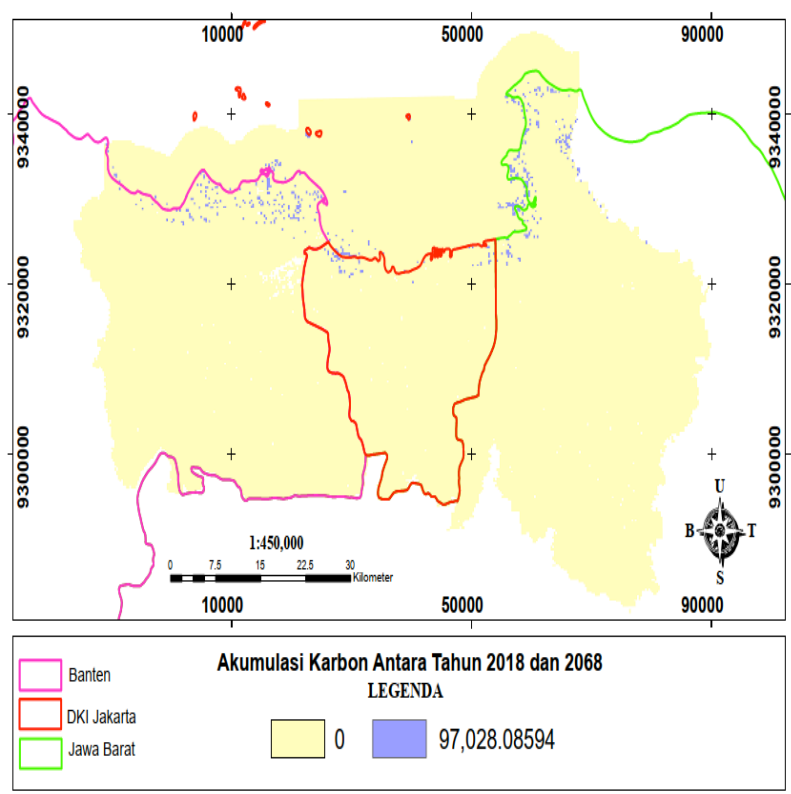

Figure 13. Carbon accumulation between 2018 and 2068

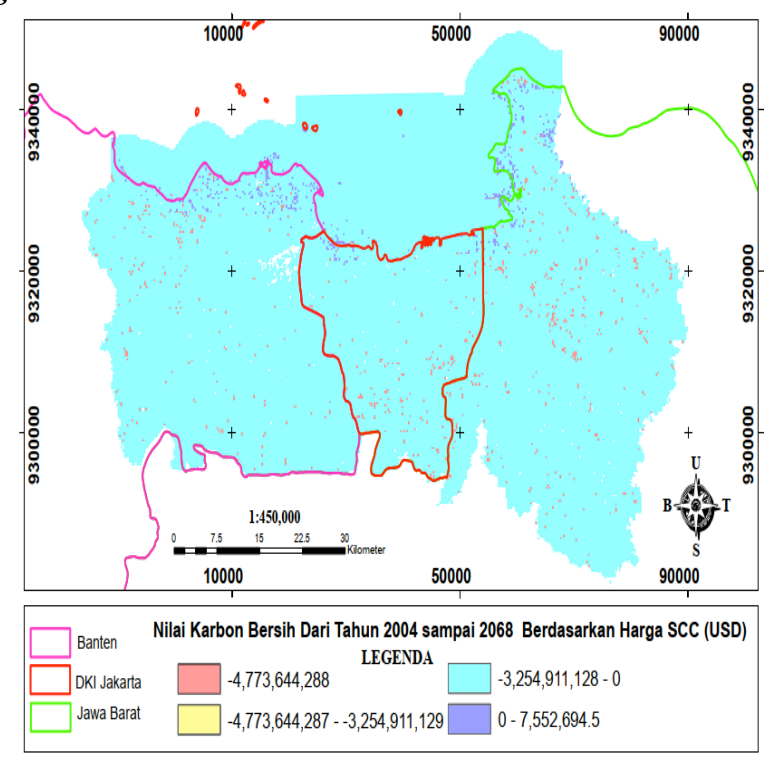

Figure 14. Net carbon values from 2004 to 2028 based on SCC prices (USD) 


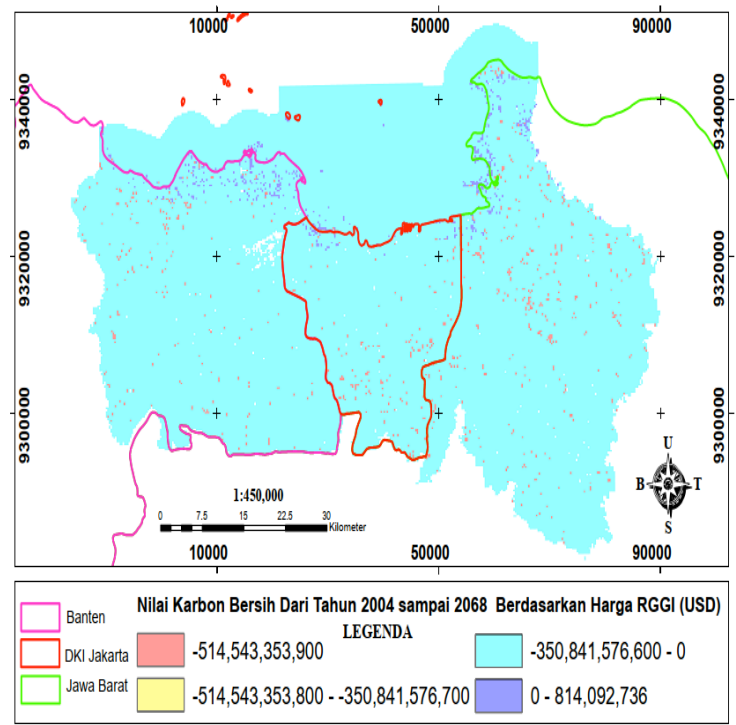

Figure 15. Net carbon values from 2004 to 2028 based on RGGI prices (USD)

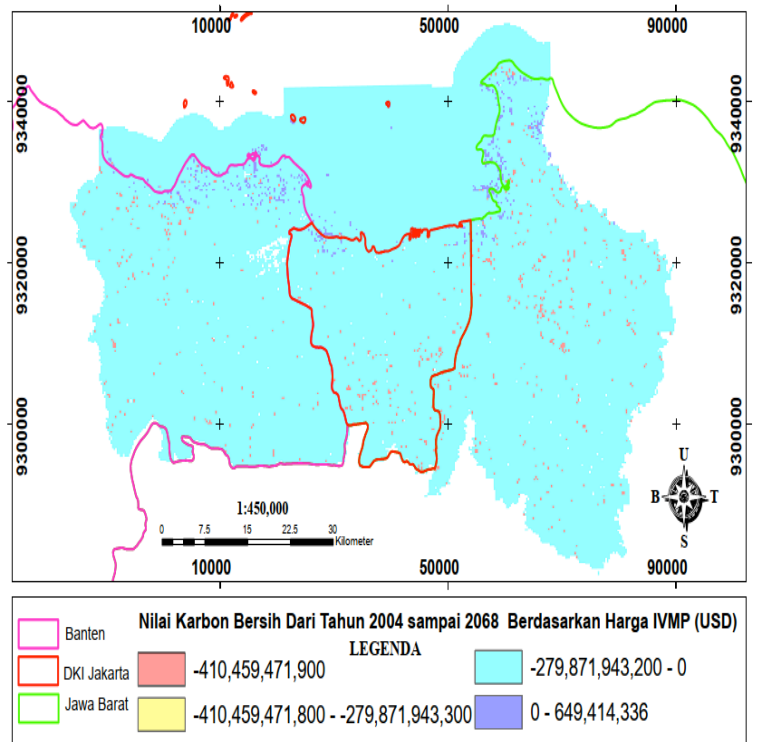

Figure 16. Net carbon values from 2004 to 2028 based on IVMP prices (USD)

In this study, the carbon price used refers to the 3 globally applicable market prices, namely Social Cost Carbon (SCC), Regional Greenhouse Gas Initiative (RGGI) and International Voluntary Market Price (IVMP). Carbon value is expressed in units of US dollars (USD), which in this study refers to the 2016 dollar price (Jerath, et al., 2016). Carbon prices based on the SCC of \$. 814,092,736 (Figure 14). Carbon prices based on RGGI for \$. 162,818,496 (Figure 15). Carbon prices based on IVMP are \$. 129,882,864 (Figure 16). The net present value obtained refers to carbon prices in 2016 based on Jerath, et al. (2016).

\section{CONCLUSION}

Changes in land use from mangrove ecosystems to water, open land, plantations, settlement, grasses, rice fields, fishpond, and vegetation have caused changes in coastal blue carbon values in Jakarta Bay from 2004-2018. Changes in carbon stock, absorption, accumulation, and carbon value based on market prices will continue to decrease, while the value of emissions will continue to increase as long as there is no effort to rehabilitate the mangrove ecosystem. This study is modelled for the next 50 years with conditions without rehabilitation efforts and assuming permanent land use and carbon prices in 2016 without a discount rate. 


\section{THANK-YOU NOTE}

The author thanks Dr. Muhammad Helmi and Hadiwijaya L. Salim M.Sc. who had been directly involved in writing this scientific paper, Ziki Faturohman who have helped in making the map layout and laboratory colleagues at PUI - PKMBRP Diponegoro University and software providers used in this study.

\section{BIBLIOGRAPHY}

Abidin,H. Z., H. Andreas.,I.Gumilar.,T.P.Sidiq. 2015. "Environmental Impacts of Land Subsidence in Urban Areas Of Indonesia." Conference: FIG Working Week 2015 From the Wisdom of the Ages to the Challenges of the Modern World Sofia, Bulgaria, 17-21May

Alongi, D.M. 2014. "Carbon Cycling and Storage in Mangrove Forests." Annual Review of Marine Science 6(1): 195-219.

Ambinari, Maya., D. Darusman., H. S. Alikodra., N.Santoso. 2016. "Penataan Peran Para Pihak Dalam Pengelolaan Hutan Mangrove Di Perkotaan.” Jurnal Analisis Kebijakan Kehutanan 13(1): 29-40.

Arifin, Taslim., E. Mustikasari. 2014. "Kondisi Pasang Surut, Arus, dan Gelombang di Teluk Jakarta." Dinamika Teluk Jakarta: Analisis Prediksi Dampak Pembangunan Tanggul Laut Jakarta (Jakarta Giant Sea Wall). Hal: 27-54.

Asyiawati, Yulia., L. S. Akliyah. 2011. "Identifikasi Dampak Perubahan Fungsi." Jurnal Perencanaan Wilayah Dan Kota 14(1): 1-13.

Ati, R. NurAfi., A. Rustam., T. L. Kepel., N. Sudirman., M. Astrid., A. Daulat., P. Mangindaan., H.L. Salim., A. A. Hutahaean. 2014. "Stok Karbon Dan Struktur Komunitas Mangrove Sebagai Blue Carbon di Tanjung Lesung, Banten.” Jurnal Segara10 Nomor 2: 119-27.

Bouillon, Steven., A. V. Borges., E. C. edamoya., K. Diele., T. Dittmar., N. C. Duke., E. Kristensen., S. Y. Lee., C. Marchand., J. J. Middelburg., V. H. R. Monroy., T. J. Smith., R. R. Twilley. 2008. "Mangrove Production and Carbon Sinks: A Revision of Global Budget Estimates. " Global Biogeochemical Cycles, Vol. 22

Neville, D. C., B. Burkhard., S. Nedkovc., L. Willemend., K. Petz., I. Palomof., E. G. Drakou., B. M. Lopez., T. M. Phearsong., K. Boyanova., R. Alkemade., B. Egoh., M. B. Dunbar., J.Maes. 2013. "A Blueprint for Mapping and Modelling Elsevier." http://dx.doi.org/10.1016/j.ecoser.2013.02.001i

Donato, D. C., Kauffman, J. B., D. Murdiyarso., S. Kurnianto., M. Stidham., M. Kanninen. 2012. "Mangrove Salah Satu Hutan Terkaya Karbon di Daerah Tropis." Brief Cifor 12: 1-12.

Donato, D.C., J.B. Kauffman., D. Murdiyarso., S. Kurnianto., M. Stidham., M. Kanninen. 2011. "Mangroves Among the Most Carbon-Rich Forests in The Tropics." Nature Geoscience4(5): 293-97. Http://Dx.Doi.Org/10.1038/Ngeo1 123.

Giri, Chandra., J. Long., S. Abbas., R.M. Murali., F.M. Qamer., B. Pengra., D. Thau. 2015. "Distribution and Dynamics of Mangrove Forests of South Asia." Journal of Environmental Management 148: 101-11.

Guerry, D.A., M.H. Ruckelshaus., K.K. Arkema., J.R. Bernhardt., G. Guannel., C.K. Kim., M. Marsik., M. Papenfus., J.E. Toft., G. Verutes., S.A.Wood., M. Beck., F. Chan., K.M.A. Chan., G. Gelfenbaum., B.D. Gold., B.S. Halpern., W.B. Labiosa., S.E. Lester., P.S. Levin., M.M. Field., M.L. Pinsky., M. Plummer., S. Polasky., P. Ruggiero., D.A. Sutherland., H. Tallis., A. Day., J. Spencern. 2012. "Modeling Benefits from Nature: Using Ecosystem Services to Inform Coastal and Marine Spatial Planning." International Journal of Biodiversity Science, Ecosystem Services and Management 8(1-2): 107-21.

Helmi, Muhammad., A. Satriadi., A. A. D. Suryoputro., J. Marwoto., H. Setiyono., Hariyadi. 2018. "Rehabilitation Prior Ity Area Assessment on Death Coral Using Cell Based Modeling Approach at Parang Islands, Karimunjawa National Park, Indonesia". International Jurnal of Civil Engineering and Technology Vol 9, Hal:2949-2961

Houghton, R A. 2003. "Revised Estimates of The Annual Net Flux of Carbon to The Atmosphere from Changes in Land Use And Land Management 1850 - 2000": 378-90.

Jerath, Meenakshi., M. Bhata., V.H. Rivera-Monroy., E. Castañeda-Moya., M. Simard., R.R. Twilley. 2016. "The Role ff Economic, Policy, And Ecological Factors in Estimating the Value of Carbon Stocks in Everglades Mangrove Forests, South Florida, USA.” Environmental Science and Policy 66: 160-69. 
Http://Dx.Doi.Org/10.1016/J.Envsci.2016.09.005.

Kusuma, Anma Hari., T. Prartono., A.S. Atmadipoera. 2013. "SebaranPolutanLogamBeratTerlarut Dan Sedimen Di PerairanTeluk Jakarta", DinamikaTeluk Jakarta: AnalisisPrediksiDampak Pembangunan TanggulLaut Jakarta (Jakarta Giant Sea Wall) hal: 1-16

Lubis, Ali Arman., B. Aliyanta., Y. Menry. 2007. "Estimation of Sediment Accumulation Rate In Jakarta Bay Using Natural Radionuclide Unsupported 210 Pb." Indo. J. Chem7(3) Hal: 309-313 309

Majid, Ilham., M.H.I. Al Muhdar., F.Rohman., I.Syamsur. 2016. "KonservasiHutan Mangrove Di PesisirPantai Kota Ternate TerintegrasidenganKurikulumSekolah.” JurnalBioedukasiVol 4 No (2) Hal: 488-492.

MEA. 2005. 5 Ecosystems Millennium Ecosystem Assesment: Ecosystems and Human Well-Being. Health Synthesis.

Murdiyarso, Daniel., J. Purbopuspito., J. B. Kauffman., M. W. Warren., S. D. Sasmito., D. C. Donato., S. Manuri., H. Krisnawati., S. Taberima., S. Kurnianto. 2015. "The Potential of Indonesian Mangrove Forests for Global Climate Change Mitigation." Nature Climate Change 5(12): 1089-92.

Nelson, E., D. Ennaanay., S. Wolny., N. Olwero., K. Vigerstol., D. P. Ton., G. Mendoza., J. Aukema., J. Foster., J. Forrest., D. Cameron., K. Arkema., E. Lonsdorf., C. Kennedy., G. Verutes., C. K. Kim., G. Guannel., M. Papenfus., J. Toft., M. Marsik., J. Bernhardt., R. Griffin., K. Glowinski., N. Chaumont., A. Perelman., M. Lacayo., L. Mandl., P. Hamel., A. L. Vogl., L. Rogers., W. Bierbowe., D. Denu., J. Douglass. 2018. Invest Documentation.

P2O-LIPI. 2017. "5 dekade LIPI di Teluk Jakarta: Riview Penelitian Oseanografi di Teluk Jakarta 19702015": 128.

Parawansa, Indar. 2007. "Pengembangan Kebijakan Pembangunan Daerah Dalam Pengelolaan Hutan Mangrove Di Teluk Jakarta Secara Berkelanjutan. "Tesis Sekolah Pascasarjana Institut Pertanian Bogor

Pendleton, Linwood., D. C. Donato., B. C. Murray., S. Crooks., W. A. Jenkins., S. Sifleet., C. Craft., J.W. Fourqurean., J.B. Kauffman., N. Marba., P. Megonigal., E. Pidgeon., D. Herr., D.Gordon., A. Baldera. 2012. "Estimating Global 'Blue Carbon' Emissions from Conversion and Degradation of Vegetated Coastal Ecosystems." Plos One7(9).

Pranowo, W. S., T. Arifin., A. Heriati. 2014. "Sirkulasi Arus Perairan Teluk Jakarta Pra Dan Pasca-Konstruksi Jakarta Giant Sea Wall." Dinamika Teluk Jakarta: Analisis Prediksi Dampak Pembangunan Tanggul Laut Jakarta (Jakarta Giant Sea Wall): 57-68.

Prasetyo, Y., B. D. Yuwono., Z. Ramadhanis. 2018. "Spatial Analysis of Land Subsidence and Flood Pattern Based on Dinsar Method In Sentinel Sar Imagery And Weighting Method In Geo-Hazard Parameters Combination In North Jakarta Region." In IOP Conference Series: Earth And Environmental Science.

PTPIN, Master Plan. 2014. "Master Plan PengembanganTerpadu Pesisir Ibukota Negara (PTPIN)." : 1-114.

Saprudin dan Halidah. 2012. "Potensi Dan Nilai Manfaat Jasa Lingkungan Hutan Mangrove Di Kabupaten Sinjai Sulawesi Selatan." Penelitian Hutan Dan Konservasi Alam 9(3): 213-19.

Sudirman, Nasir., M. Helmi., N.S Adi. 2018. "Modeling Mangrove Blue Carbon Ecosystem Service In Jakarta Bayas An Impact Of Coastal Development". Conference 3rd ICENIS.

Suzana, B. O. L., F. Ahmad., J. Timban., R. Kaunang. 2011. "Valuasi Ekonomi Sumberdaya Hutan Mangrove di Desa Pales Kecamatan Likupang Barat Kabupaten Minahasa Utara." ASE Vol 7: 29-38. 